\title{
Anestesi untuk Seksio Sesarea pada Pasien dengan Ventrikel Septal Defek
}

\author{
Dwiana Sulistyanti*), Yusmein Uyun**) \\ ${ }^{*}$ Departemen Anestesiologi \& Terapi Intensif Fakultas Kedokteran Universitas Mulawarman Samarinda, ${ }^{* *}$ SMF \\ Anestesiologi dan Terapi Intensif Fakultas Kedokteran Universitas Gadjah Mada-RSUP Dr. Sardjito Yogyakarta
}

\begin{abstract}
Abstrak
Pasien hamil yang memiliki penyakit jantung kongenital merupakan tantangan untuk dokter kandungan dan dokter anestesi ketika pasien akan menjalani operasi sesarea mergensi. Dalam penanganan pasien hamil yang beresiko tinggi dibutuhkan pemahaman yang baik tentang perubahan hemodinamik saat kehamilan, dan efek perubahan tersebut terhadap pasien dan fisiologi jantung abnormal. Penyakit jantung kongenital merupakan penyebab paling banyak masalah jantung pada pasien hamil tetapi pasien dengan defek yang tidak dikoreksi merupakan kasus yang jarang pada bagian kandungan. Pada populasi dewasa, lesi jantung kongenital kronik yang tidak diperbaiki merupakan situasi yang sulit bagi dokter anestesi karena tingginya resiko anestesi obstetrik. Laporan kasus ini menjelaskan tentang keberhasilan operasi sesar pada pasien penyakit jantung kongenital dalam kondisi emergensi. Wanita umur 28 tahun, G1P0A0 dengan umur kehamilan 38-39 minggu datang ke rumah sakit untuk melahirkan. Wanita ini memiliki riwayat penyakit jantung kongenital ventrikel septal defek (VSD). Kemudian dilakukan operasi sesar dengan anestesi umum dengan gas inhalasi dan obat intravena. Cefotaxim dan gentamisin diberikan untuk propilaksis endokarditis bakteri. Bayi lahir dengan skor APGAR 8 setelah menit ke 5. Pasca operasi pasien dibawa ke ruang ICU untuk monitoring ketat tanda vital dan perawatan pasca operasi. Laporan kasus ini menjelaskan tentang kondisi pasien pre-operasi, intra-operasi dan pasca-operasi.
\end{abstract}

Kata kunci: ventrikel septal defek, operasi sesar darurat, anestesi umum

\section{Anesthesia for a Cesarean Section in a Patient with Ventricular Septal Defect}

\begin{abstract}
Pregnant patient with congenital heart disease (CHD) make for a unique challenge to the obstetrician and anesthesiologist, when the patient has to undergo emergency cesarean section. Managing high-risk parturient requires a thorough understanding of the hemodynamic changes of pregnancy, its effect on the patient and physiology of the abnormal heart. CHD is becoming the most common source of cardiac problem in pregnant patient but non-corrected cardiac defect patient are rare cases in the obstetric departement. In adult population, chronic non-palliated congenital heart lession present new difficult situation for the anesthesiologist working with high-risk obstetric anesthesia. This case report makes a successful cesarean section in a CHD patient in emergency condition. A 28 year old female, gravida 1 at 38-39 weeks gestation age admitted to our hospital for delivery. She had a history of CHD with ventricular septal defect. She was prepared for cesarean section under general anesthesia with inhaled and intravenous anesthetic agents. Cefotaxim and gentamicin were administered for prophylaxis against bacterial endocarditis. The newborn was delivered quickly with APGAR score 8 after 5 minutes. Postoperatively, the patient was admitted to the intensive care unit (ICU) for close monitoring of vital signs and post-operative care. The case report will include details in pre-operative, intra-operative and postoperative outcome of the patient.
\end{abstract}

Key words: Ventricular septal defect, cesarean section emergency, general anesthesia 


\section{Pendahuluan}

Prevalensi penyakit jantung kongenital pada kehamilan relatif tidak ada perubahan selama beberapa dekade terakhir ini, rata-rata $0,4-4,1 \%{ }^{1}$ Wanita hamil dengan kelainan jantung kongenital merupakan sebuah tantangan yang unik bagi dokter kandungan dan dokter anestesi ketika pasien akan melakukan persalinan baik secara normal maupun operasi sesar. Karena dibutuhkan pemahaman yang lebih dalam tentang pengaruh kehamilan terhadap respon hemodinamik pada pasien dengan kondisi jantung yang mempunyai defek. Kerjasama multidisiplin berbagai ilmu yang terlibat langsung, seperti dokter kandungan, dokter jantung dan dokter anestesi, harus dibina dengan baik, karena ini merupakan kunci untuk penanganan yang optimal bagi pasien ibu hamil dengan kelainan jantung kongenital yang akan melakukan operasi non kardiak. ${ }^{2}$ Pasien ibu hamil dengan kelainan jantung kongenital mempunyai resiko yang lebih besar untuk terjadinya komplikasi obstetri dan mempunyai morbiditas yang lebih tinggi selama proses pembedahan. Ventikel septal defek merupakan kelainan jantung kongenital yang paling banyak ditemukan, sekitar 1,5 sampai 2,5 dari 1000 wanita hamil yang melahirkan. VSD yang tidak disertai dengan defek jantung yang lain biasanya masih bisa ditoleransi selama kehamilan, tetapi masih mungkin berhubungan dengan kejadian aritmia dan gagal jantung kongestif.

Penurunan tekanan darah yang cukup besar, yang timbul selama atau sesudah persalinan atau sesudah tindakan anestesi, dapat mengakibatkan terjadinya perubahan arah shunting. ${ }^{2}$ Pemilihan tehnik anestesi yang akan dipergunakan sebaiknya diambil berdasarkan kondisi ibu hamil dan kelainan jantung yang terjadi. Pada prinsipnya tehnik anestesi general maupun regional dapat dilakukan, tetapi hindari penggunaan tehnik anestesi yang dapat mengakibatkan perubahan hemodinamik yang signifikan ${ }^{3}$ Secara fisiologis terjadi perubahan sistem kardiovaskuler pada ibu hamil, hal ini penting untuk dipahami karena perubahan pada sistem kardiovaskuler ini akan berpengaruh juga terhadap kelainan jantung yang ada. $^{3}$
Dalam laporan kasus ini akan dijelaskan tentang penanganan ibu hamil dengan kelainan jantung kongenital ventrikel septal defek yang akan dilakukan operasi sesar emergensi.

\section{Kasus}

\section{Anamnesa}

Wanita, umur 28 tahun, dengan G1P0A0 hamil 3839 minggu, masuk rumah sakit jam 09.00 WITA (Waktu Indonesia bagian tengah) dengan keluhan kencang-kencang hendak melahirkan. Pasien datang dengan membawa hasil ekokardiografi yang menyatakan bahwa pasien mempunyai kelainan jantung VSD. Setelah dilakukan pemeriksaan oleh dokter kandungan diputuskan untuk dilakukan operasi sesar pada pasien ini. Jam 09.30 WITA (Waktu Indonesia bagian tengah) pasien dikonsulkan untuk tindakan anestesi. Dari anamnesa didapatkan keterangan bahwa pasien baru mengetahui mempunyai penyakit jantung pada saat pasien duduk di sekolah menengah atas, karena pasien sering mengalami pingsan. Tidak ada riwayat biru-biru pada bibir atau kuku sebelumnya, tidak ada riwayat sering sesak nafas sebelumnya dan tidak ada riwayat lekas lelah bila beraktivitas berlebihan atau menaiki tangga. Setelah hamil besar, pasien baru sering merasa lelah, tidak nyaman kalau tidur terlentang tanpa bantal, tapi tidak merasa sesak. Tidak ada riwayat sakit asma, sakit kencing manis, maupun alergi obat-obatan. Tidak ada riwayat tekanan darah tinggi sebelumnya. Tidak ada riwayat operasi sebelumnya. Pasien tidak mengkonsumsi obat pengencer darah ataupun obat jantung lainnya. Makan terakhir jam 2 malam, tapi masih minum air putih sampai jam 6 pagi. Berat badan pasien $68 \mathrm{~kg}$.

\section{Pemeriksaan Fisik}

Preoperasi didapatkan pasien komposmentis, kesakitan karena his yang berulang, tekanan darah 150/100 mmHg, laju nadi $110 \mathrm{x} /$ menit, laju napas 20x/menit, saturasi oksigen $99 \%$, dan suhu afebris. Pada pemeriksaan kepala tidak ditemukan napas cuping hidung, bibir tidak sianosis, pemeriksaan leher dalam batas normal. Pemeriksaan thoraks didapatkan bentuk dan gerak dada simetris, dari pemeriksaan auskultasi 
jantung ditemukan murmur, pemeriksaan paru dalam batas normal, pemeriksaan abdomen sesuai dengan umur kehamilan, gerak janin ada. Pemeriksaan ekstremitas didapatkan akral hangat, ujung jari tidak sianosis dan tidak ditemukan clubbing finger.

\section{Pemeriksaan Laboratorium}

Didapatkan kadar hemoglobin 11,6 g/dL, kadar hematokrit $34,8 \%$, leukosit $10.120 / \mu \mathrm{L}$, trombosit $195.000 \mu / \mathrm{L}$, bleeding time 2 menit 3 detik, clotting time 7 menit, gula darah sewaktu $89 \mathrm{mg} /$ $\mathrm{dL}$, albumin $3,4 \mathrm{~g} / \mathrm{dL}$, ureum $15 \mathrm{mg} / \mathrm{dL}$, kreatinin $0,7 \mathrm{mg} / \mathrm{dL}, \mathrm{Hbs} \mathrm{Ag}$ non reaktif, HIV non reaktif. Pemeriksaan foto thoraks: tidak dilakukan. Hasil pemeriksaan ekokardiografi: didapatkan dimensi ruang-ruang jantung dilatasi LV, kontraktilitas LV dalam batas normal, EF: 68\%, Left Ventrikel Hipertrofi tidak ditemukan, Wall motion analysa global normokinetik, tidak tampak PDA, katupkatup dalam batas normal, VSD perimembranous besar (ukuran 1,36 cm) dengan left to right shunt,

\section{Gambar 1. EKG}
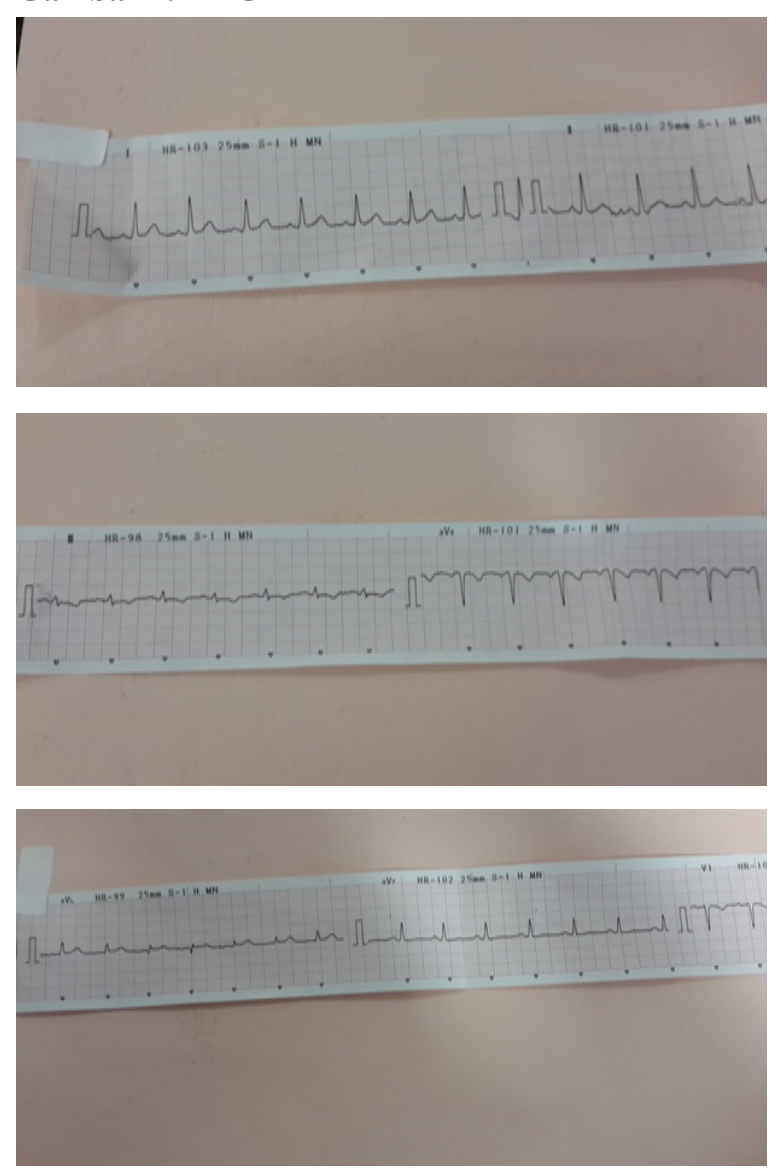

fungsi sistolik LV dalam batas normal, fungsi diastolik LV terganggu dan tidak ditemukan hipertensi pulmonal.

Darianamnesa, pemeriksaanfisikdan pemeriksaan penunjang diambil kesimpulan pasien termasuk status fisik ASA III. Kemudian pasien diberikan informed consent. Setelah mendapatkan injeksi antibiotik cefotaxime 2 gram intravena, Gentamisin $80 \mathrm{mg}$ intravena, dan midazolam 2,5 $\mathrm{mg}$ intravena pasien diantar ke ruang operasi. Saat pasien dimasukkan ke dalam ruang operasi didapatkan tanda vital: tekanan darah 126/68 $\mathrm{mmHg}$, laju nadi 94x/menit, laju napas 20x/ menit, saturasi oksigen 100\%. Induksi anestesi dimulai pada pukul 10.30 WITA. Induksi dilakukan dengan memberikan propofol 100 mg intravena perlahan, diikuti pemberian rocuronium $40 \mathrm{mg}$, dan fentanil $100 \mu \mathrm{g}$ yang diberikan secara perlahan. Tanda vital setelah induksi tekanan darah $102 / 49 \mathrm{mmHg}$, laju nadi 110x/menit, saturasi 98\%. Kemudian dilakukan intubasi dengan endotracheal tube no. 6,5 dengan kedalaman $18 \mathrm{~cm}$. Endotracheal tube dihubungkan dengan mesin anestesi dan pada saat operasi berlangsung pemeliharaan anestesi menggunakan $\mathrm{O}_{2} \quad(70 \%), \quad \mathrm{N}_{2} \mathrm{O} \quad(30 \%)$ dan sevofluran 1 vol\%. Obat inotropik, dobutamin, dan obat vasoaktif disiapkan tetapi tidak disambungkan dengan pasien. Setelah bayi lahir diberikan fentanil $100 \mu \mathrm{g}$. Hemodinamik selama
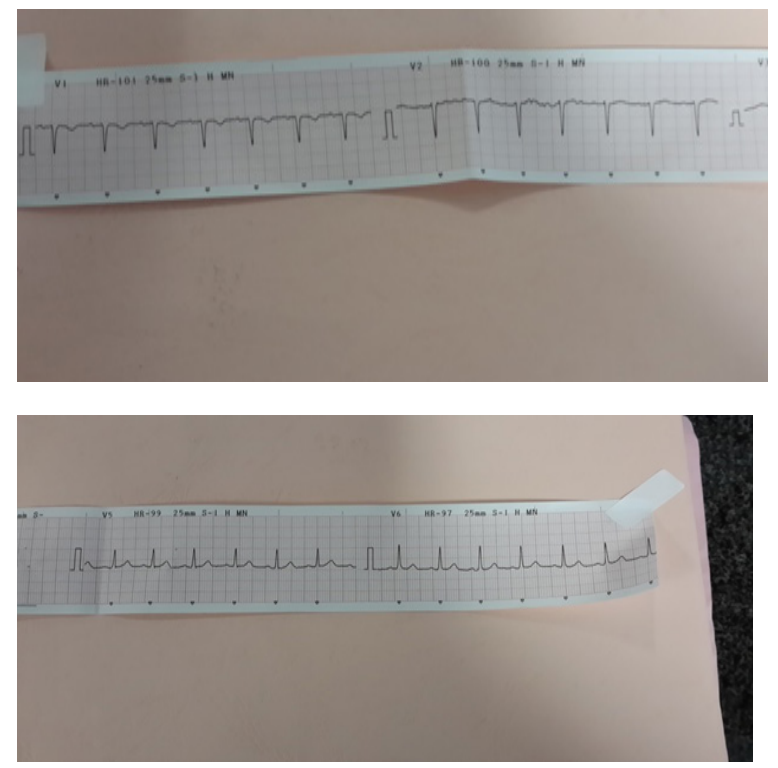
masa operasi berkisar tekanan darah sistolik 102$128 \mathrm{mmHg}$, tekanan darah diastolik 49-68 $\mathrm{mmHg}$, laju nadi $73-99 x / m e n i t$, laju napas $16 x /$ menit dengan kontrol ventilasi, saturasi oksigen 100\%.

Lahir bayi laki-laki dengan apgar score 8 setelah 5 menit. Oxytocin 20 IU diberikan dengan cara di drip perlahan dalam $500 \mathrm{cc}$ kristaloid. Jumlah cairan yang diberikan durante operasi $\pm 750 \mathrm{cc}$ kristaloid. Perdarahan berkisar 400cc, dengan urin output $350 \mathrm{cc}$. Setelah operasi selesai dilakukan reversal terhadap pelemas otot, pasien napas spontan, dan dilakukan ekstubasi.

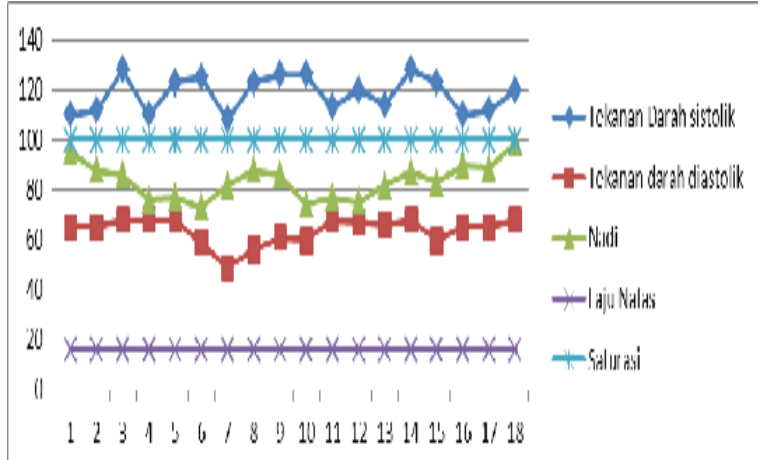

Grafik 1. Hemodinamik Durante Operasi

Operasi berlangsung selama 1 jam 15 menit. Pasca operasi diberikan obat analgetik berupa fentanil patch $12 \mu \mathrm{g}$ dan analgetik drip 16 tetes/ menit (tramadol $200 \mathrm{mg}$ dan cedantron $4 \mathrm{mg}$ dalam RL $500 \mathrm{cc}$ ). Kemudian pasien dipindahkan ke ruang ICU. Kondisi pasien di ICU, pasien sadar tetapi masih mengantuk, dengan tanda vital tekanan darah 130/83 mmHg, dengan MAP $90 \mathrm{mmHg}$, laju nadi 76x/menit, laju napas 16x/ menit, saturasi $100 \%$ dengan oksigen nasal kanul $3 \mathrm{~L} /$ menit, suhu $33,8^{\circ} \mathrm{C}$, EKG normal

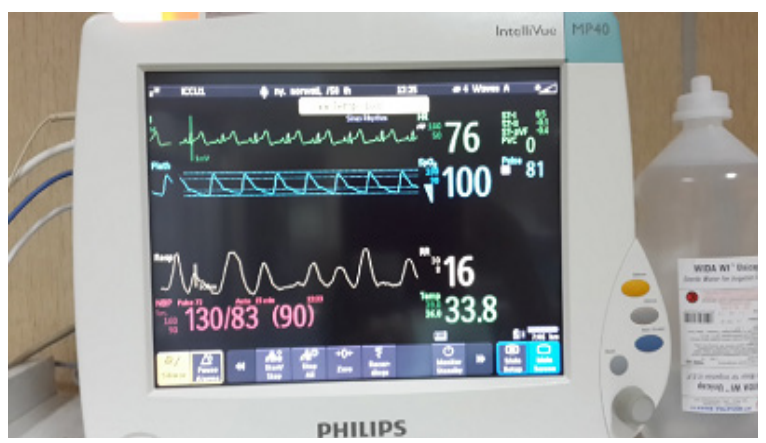

Gambar 2. Tanda Vital Post Operasi di ICU sinus ritme. Hasil laboratorium pasca operasi: kadar hemoglobin $11 \mathrm{~g} / \mathrm{dL}$, leukosit $17.800 / \mu \mathrm{L}$, kadar hematokrit 33\%, trombosit $193.000 \mu / \mathrm{L}$, gula darah sewaktu $132 \mathrm{mg} / \mathrm{dL}$, ureum $15 \mathrm{mg} /$ $\mathrm{dL}$, kreatinin $0,7 \mathrm{mg} / \mathrm{dL}$, natrium $132 \mathrm{mmol} / \mathrm{L}$, kalium 3,8 mmol/L, calsium 9,4 mg/dL, khlorida $104 \mathrm{mmol} / \mathrm{L}$, magnesium 2,0 mg/dL. Pasien diobservasi di ruang ICU selama $2 \times 24$ jam, selama di ICU kondisi pasien stabil dan hari ke 3 pasien dipindahkan ke ruang perawatan biasa. Hari kelima pasien dipulangkan.

\section{Pembahasan}

Pada kehamilan normal, ibu hamil mengalami banyak perubahan fisiologi pada berbagai sistem organ. Perubahan pada sistem kardiovaskuler meliputi penurunan tahanan pembuluh darah sistemik (systemic vascular resistance/SVR), peningkatan volume darah dan peningkatan curah jantung (cardiac output) sekunder akibat peningkatan laju nadi dan volume sekuncup (stroke volume). Perubahan hemodinamik yang terbesar timbul selama kehamilan, persalinan dan periode pasca persalinan. Pada ibu hamil yang mempunyai kelainan jantung, kegagalan jantung juga sering timbul bersamaan pada waktu-waktu tersebut. Penekanan pada jantung selama kehamilan, persalinan dan periode pasca persalinan dapat menimbulkan gagal jantung dengan derajat yang berbeda-beda pada pasien dengan kelainan jantung ini, selain itu pemberian obat-obatan untuk kelainan jantungnya juga dapat mempengaruhi penanganan dalam anestesi. ${ }^{2}$

Ventrikel septal defek (VSD) merupakan penyakit jantung kongenital yang paling sering. Tidak seperti atrial septal defek (ASD), pada umumnya kelainan jantung VSD ini 40\% dapat menutup spontan pada umur 2 tahun dan 90 $\%$ pada umur 10 tahun. ${ }^{4}$ Wanita dengan VSD tanpa disertai kelainan jantung lain biasanya bisa mentoleransi kehamilan jika pintasan yang terjadi kecil sampai sedang dan jika tekanan arteri pulmonalnya normal. ${ }^{2}$ Adanya hipertensi pulmonal karena pintasan dari kiri ke kanan (left to right shunt) akan meningkatkan resiko komplikasi selama kehamilan. Masalah seperti aritmia, disfungsi ventrikel dan hipertensi 
pulmonal yang bertambah progresif akan terjadi pada pasien-pasien dengan pintasan (shunts) dan atau adanya hipertensi pulmonal sebelumnya. ${ }^{5}$

Berkembangnya pintasan (shunt) relatif tergantung pada tahanan paru dan pembuluh darah sistemik serta ukuran dari defek. Jika defek pada jantungnya kecil, maka aliran darah pulmonal akan sedikit meningkat. Pasien dengan VSD restriktif kecil yang mempunyai PVR normal mempunyai prognosis yang baik dan mempunyai resiko sedang untuk terjadinya endokarditis dan berkembangnya sindroma Eisenmenger dan hipoksemia. Shunting akan meningkat jika SVR meningkat oleh karena nyeri dan adanya pelepasan katekolamin. Jika terjadi penurunan SVR yang besar (contoh setelah dilakukan spinal anestesi) maka akan terjadi pintasan yang berbalik arah (right to left shunt) dan menyebabkan hipoksia. ${ }^{2}$ Dengan memahami perubahan fisiologi ibu hamil dan patofisiologi kelainan yang jantung yang ada diharapkan kita dapat melakukan tindakan anestesi yang optimal bagi pasien. Pada prinsipnya tehnik anestesi umum maupun regional dapat digunakan pada pasien dengan kelainan jantung kongenital, tetapi dengan perhatian yang lebih terutama pada patofisiologi pasien dan hemodinamik yang ingin dicapai. ${ }^{3,6,7}$ Tujuan utama penatalaksanaan anestesi pada ibu hamil dengan kelainan jantung kongenital adalah optimalisasi kondisi ibu selama hamil, monitor hal-hal yang membuat perburukan kondisi ibu, meminimalkan penambahan beban pada sistem kardiovaskuler dari persalinan sampai periode pasca persalinan. ${ }^{3}$

Perlu juga diperhatikan beberapa faktor seperti pencegahan terhadap masuknya gelembung udara melalui infus intravena, ketika direncanakan akan dilakukan epidural anestesi, untuk identifikasi ruang epidural sebaiknya menggunakan cairan saline, pemberian obat anestesi melalui epidural sebaiknya perlahan, karena bila terlalu cepat akan meyebabkan SVR menurun sehingga terjadi pintasan berbalik arah dan hipoksia maternal. Berikan oksigen pada pasien-pasien dengan regional anestesi. Cegah terjadinya hipoksemia, hiperkarbi dan asidosis karena akan meningkatkan tahanan pembuluh darah pulmonal (PVR), yang akan mengakibatkan pintasan berbalik arah.
Penggunaan regional anestesi memerlukan perhatian yang khusus. ${ }^{7}$ Anestesi spinal single shot dihindari, karena perubahan hemodinamik yang terjadi cukup besar. ${ }^{7,8}$ Pada pasien ini dilakukan tindakan anestesi umum karena operasi sesar dilakukan emergensi sehingga untuk efisiensi waktu dan stabilitas hemodinamik menjadi prioritas. Pemberian premedikasi masih dapat ditoleransi pasien dengan baik. ${ }^{6}$ Pasien ini mendapatkan injeksi midazolam 2,5 mg intravena perlahan sebelum dilakukan induksi anestesi dan memberikan hasil yang cukup baik dimana ibu tampak lebih tenang dan jalan nafas tetap terjaga. Induksi anestesi dengan menggunakan inhalasi sevoflurane disarankan dan ditoleransi dengan baik oleh pasien-pasien dengan berbagai macam kelainan jantung kongenital karena sevoflurane tidak terlalu mendepresi jantung. Propofol juga dapat digunakan untuk induksi dan pemeliharaan anestesi pada pasien dengan kelainan jantung kongenital tetapi perlu diperhatikan dengan baik efek vasodilatasi vena maupun arteri yang disebabkan oleh propofol. Pilihan yang baik untuk pasien-pasien dengan gangguan fungsi miokardium adalah etomidat, karena etomidat mempunyai efek yang tidak terlalu menekan kontraksi otot jantung dan hemodinamik. Opioid dapat digunakan juga pada pasien dengan kelainan jantung kongenital. ${ }^{6}$ Pasien ini mendapatkan obat induksi propofol $100 \mathrm{mg}$ intravena yang diberikan perlahan-lahan, untuk mencegah terjadinya efek vasodilatasi vena dan arteri.

Dilanjutkan dengan pemberian pelemas otot rocuronium $40 \mathrm{mg}$ intravena, dengan harapan onset bisa lebih cepat dan tidak terjadi pelepasan histamin. Tidak dilakukan rapid sequence induction mengingat pasien mempunyai waktu puasa yang cukup. Untuk mencegah kemungkinan terjadinya aspirasi, dilakukan ventilasi tekanan positif dengan memberikan ventilasi yang tidak terlalu kuat. Setelah onset pelemas otot tercapai, diberikan fentanil $100 \mu \mathrm{g}$, sebagai analgetik dan untuk mencegah gejolak hemodinamik saat intubasi. Setelah 30 detik penyuntikan fentanil, dilakukan intubasi dengan pipa endotrakheal (endotracheal/ETT) no 6,5. Selama kehamilan, nasofaringeal, orofaringeal dan mukosa traktus respirasi lebih udem, sehingga mukosa menjadi 
lebih mudah berdarah saat dilakukan intubasi dan pengisapan lendir (suctioning). ${ }^{7}$ Oleh karena itu digunakan ETT dengan ukuran lebih kecil, dan harus hati-hati saat melakukan suctioning. Proses intubasi (memasukkan ETT kedalam trachea) juga harus dilakukan cepat karena ibu hamil mempunyai cadangan oksigen yang rendah karena ada penurunan functional residual capacity (FRC) pada ibu hamil. ${ }^{7}$ Selama operasi berlangsung ventilasi dikontrol, saturasi pasien selama operasi $100 \%$. Lahir bayi laki-laki dengan apgar score 8 setelah 5 menit. Setelah bayi lahir, diberikan lagi fentanil $100 \mu \mathrm{g}$, untuk mencegah terjadinya peningkatan SVR dan peningkatan nadi karena stimulasi bedah, dan untuk memperbaiki kontraksi uterus diberikan oxitocin 20 IU didrip dalam RL $500 \mathrm{cc}$. Pemberian oxitocin dilakukan secara perlahan untuk menghindari peningkatan PVR yang dapat mengakibatkan pintasan berbalik arah (right to left). ${ }^{7}$

Jumlah cairan yang diberikan durante operasi \pm $750 \mathrm{cc}$ kristaloid. Perdarahan berkisar $400 \mathrm{cc}$, dengan urin output $350 \mathrm{cc}$. Setelah operasi selesai, dilakukan reversal terhadap pelemas otot, pasien napas spontan, dan dilakukan ekstubasi. Operasi berlangsung selama 1 jam 15 menit. Pasca operasi diberikan obat analgetik berupa fentanil patch 12 $\mu \mathrm{g}$ dan analgetik drip 16 tetes/menit (tramadol $200 \mathrm{mg}$ dan cedantron $4 \mathrm{mg}$ dalam RL $500 \mathrm{cc}$ ). Penggunaan fentanil patch pada pasien post operasi sesar masih pro dan kontra. Pertimbangan pada pasien ini menggunakan fentanil patch adalah untuk menjaga hemodinamik pasien mengingat pasien memiliki kelainan jantung kongenital sehingga kondisi hemodinamiknya harus benar-benar dijaga untuk menghindari terjadinya pintasan yang berbalik arah (right to left shunt). Namun demikian, efek samping dari fentanil patch pada ibu dan bayi tetap harus dimonitoring dengan ketat untuk menghindari hal-hal yang tidak diinginkan dari efek samping penggunaan fentanil patch tersebut.

Kemudian pasien dipindahkan ke ruang ICU. Untuk dilakukan monitoring ketat terhadap tanda vital pasien dan terhadap komplikasi pasca operasi seperti aritmia, disfungsi ventrikel dan hipertensi pulmonal. Selama perawatan di ICU hemodinamik pasien dalam keadaan stabil, pasien dapat mobilisasi dengan cepat sehingga pasien hanya dirawat di ICU selama 2x24 jam. Hari ketiga pasien pindah ke ruang perawatan biasa, dan hari kelima pasien boleh pulang.

Pasien ini mendapatkan antibiotik profilaksis endokarditis atas saran dokter spesialis jantung, yaitu antibiotik cefotaxime 2 gram intravena dan gentamisin $80 \mathrm{mg}$ intravena setengah jam sebelum operasi yang dilanjutkan dengan injeksi cefotaxim 1 gram setelah 6 jam selesai operasi. The American Heart Association (AHA) sudah memberikan panduan tentang pemberian antibiotik profilaksis endokarditis. Untuk persalinan operasi sesar maupun pervaginam jika tidak ada tanda infeksi tidak diperlukan profilaksis endokarditis kecuali pasien-pasien dengan resiko tinggi. ${ }^{7,9}$ Pada tahun 2007, AHA secara nyata merubah panduan pemberian antibiotik profilaksis endokarditis, dimana ada 2 indikasi dalam pemberian antibiotik profilaksis endokarditis ini. Indikasinya terdiri dari indikasi jantung dan indikasi bedah/prosedur tindakan. ${ }^{10}$ Profilaksis infeksi endokarditis tidak direkomendasikan pada tindakan gastrointestinal atau genitorinaria yang sederhana dimana tidak dilakukan insisi pada mukosa, contohnya simple endoscopy dan cystoureteroscopy, tetapi direkomendasikan pada tindakan bedah dimana dilakukan insisi pada mukosa. ${ }^{6,10}$

Keberhasilan penanganan ibu hamil dengan kelainan jantung selain tergantung pada pemahaman tentang perubahan fisiologi ibu hamil dan pemahaman tentang patofisiologi kelainan jantung yang terjadi, juga bergantung pada kerjasama tim yang baik yang terlibat langsung dengan penanganan pasiennya, seperti kardiologis, dokter kandungan, dokter anestesi, dokter anak bahkan intensivis. Apabila ditemukan pasien dengan kelainan jantung kongenital pada masa-masa awal kehamilan sebaiknya dilakukan diskusi yang mendalam semua anggota tim untuk menentukan tindakan apa yang akan dilakukan agar mendapatkan hasil yang optimal baik untuk ibunya maupun untuk janin/bayinya. Sedangkan untuk operasi emergensi waktu yang dibutuhkan untuk mengoptimalisasi pasien sangat minimal, hal ini 
dapat meningkatkan komplikasi akibat kelainan jantung yang ada. Tidak ada pedoman evidencebased untuk penanganan perioperatif pasienpasien dengan kelainan jantung kongenital. ${ }^{11}$

\section{Simpulan}

Evaluasi preanestesi yang baik pada pasienpasien dengan kelainan jantung, menentukan rencana anestesi dan persiapan yang adekuat akan menghantarkan kita pada anestesi yang aman dan optimal untuk pasien. Pada prinsipnya tehnik anestesi umum maupun regional dapat digunakan pada pasien dengan kelainan jantung kongenital, tetapi dengan perhatian yang lebih terutama pada patofisiologi pasien dan hemodinamik yang ingin dicapai. Kerjasama tim yang baik merupakan kunci utama untuk keberhasilan penanganan ibu hamil dengan kelainan jantung kongenital yang akan dilakukan operasi non kardiak.

\section{Daftar Pustaka}

1. Chestnut DH. Principles and practise of obstetric anesthesia. Philadelphia, Pennsylvania: Elsevier Mosby-2004;3: 70733.

2. Verma RK, Khatri SK, Pradhan C, Nath R. Anesthesia for elective cesarean section in a patient with congenital acyanotic heart disease. Anesthesia Pain \& Intensive Care 2012;16(2): 189-91.

3. Christiana CB, Jacqueline D. Management of cardiac disease in pregnancy. Continuing Education in Anesthesia, Critical Care \& Pain 2009; 9(2): 44-7.

4. Perloff JK. Survival patterns without cardiac surgery or interventional catheterization: a narrowing base. In: Perloff JK, Childs JS, eds. Congenital Heart Disease in Adults, 2nd ed. Philadelphia: WB Saunders, 1998; 15-53.
5. Weiss BM, Hess OM. Pulmonary vascular disease and pregnancy: current controversies, management strategies, and perspectives. European Heart Journal 2000; 21:104-115.

6. Dean BA. Anesthesia for the patient with congenital heart disease for noncardiac surgery. Anesthesiology 2011; 206-14.

7. Abreu LA, Madruga B, Gouvea J, Zapata Z, Bersot CD. Anesthesia for a cesarean section in a patient with a congenital heart disease and complete placenta previa. Journal Anesthesia \& Clinical Research 2012; 3(5): 23-7.

8. Marianne SC. Anesthesia for the adult patient with an unrepaired congenital cyanotic heart defect: a case report. AANA Journal 2012; 80(3):197-203.

9. Sugrue D, Blake S, Troy P, MacDonald D. Antibiotic prophylaxis againts infective endocarditis after normal delivery: is it necessary?. British Heart Journal 1980; 44:499-502.

10. Wilson W, Taubert KA, Gewitz M, Lockhart PB. Prevention of infective endocarditis: Guidelines from the American Heart Association: A guideline from the American Heart Association Rheumatic Fever, Endocarditis, and Kawasaki Disease Committee, Council on Cardiovascular Disease in the Young, and the Council on Clinical Cardiology, Council on Cardiovascular Surgery and Anesthesia, and the Quality of Care and Outcomes Researsch Interdisciplinary Working Group. Circulation 2007; 116: 1736-54.

11. Maxime C, Michael GE, Vincent C, Judi RK. Anesthesia for noncardiac surgery in adults with congenital heart disease. Anesthesiology 2009; 8(2):432-40. 


\title{
Kardiomiopati Peripartum: Manajemen Anestesi Terbaru
}

\author{
Rafidya Septica*), Isngadi**) \\ ${ }^{*}$ Departemen Anestesiologi \& Terapi Intensif Fakultas Kedokteran Universitas Gadjah Mada-RSUP Dr. Sardjito \\ Yogyakarta, ${ }^{* *}$ Departemen Anestesiologi \& Terapi Intensif Fakultas Kedokteran Universitas Brawijaya-RSUP Dr. \\ Saiful Anwar Malang
}

\begin{abstract}
Abstrak
Kardiomiopati peripartum (KMPP) atau Peripartum cardiomyopathy (PPCM) adalah kelainan jantung idiopatik dengan karakteristik disfungsi sistolik dan simptom gagal jantung pada akhir masa kehamilan atau beberapa bulan setelah kehamilan tanpa sebab lain yang mengancam jiwa maternal dengan risiko morbiditas dan mortalitas postpartum cukup tinggi. Penelitian terbaru dalam pemahaman tentang patofisiologi PPCM menunjukkan proses yang melibatkan faktor endotel dan faktor toksik kardio, seperti sFlt-1 dan 16 kDa prolaktin, sehingga kemampuan jantung beradaptasi terhadap kehamilan normal terlampaui pada ibu yang sudah rentan terhadap serangan jantung. Terapi spesifik PPCM belum dapat ditentukan. Bromokriptin yang bekerja memblok pelepasan prolaktin dari glandula pituitaria, pada beberapa penelitian awal menghasilkan perbaikan fraksi ejeksi ventrikel kiri secara bermakna. Penelitian lebih lanjut dengan jumlah sampel yang lebih besar masih harus dilakukan untuk terapi ini. Prinsip manajemen direkomendasikan sesuai dengan patofisiologi yang terjadi. Optimalisasi atau reduksi preload baik dengan reduksi natrium maupun cairan dan penggunaan diuretika, menurunkan afterload dengan vasodilator, dan memperbaiki kontraktilitas jantung dengan inotropik, dromotropik, atau inodilator adalah strategi utama yang direkomendasikan. Tidak ada perubahan strategi dalam manajemen terapi ini, tetapi pilihan teknik anestesi saat ini lebih berkembang ke analgesi/anestesi regional. Pemahaman penggunaan dosis dan konsentrasi anestetika lokal menjadi penting untuk mencapai target dalam strategi yang direkomendasikan.
\end{abstract}

Kata kunci: kadiomiopati peripartum, manajemen anestesi PPCM, anestesi regional

\section{Peripartum Cardiomyopathy: Update in Anesthesia Management}

\begin{abstract}
Peripatum cardiomyopathy (PPCM) is an idiopathic cardiomyopathy presenting with heart failure secondary to left ventricle systolic dysfunction towards the end of pregnancy or in the months following delivery, where no other cause for heart failure is identified, life-threatening, and postpartum high morbidity and mortality risk. Recent studies in the understanding of PPCM pathophysiology indicate that there's processes involving endothelial and cardio-toxic factors such as e.g. sFlt-1 and $16 \mathrm{kDa}$ prolactin, leading the heart's capacity to adapt to a normal pregnancy may be exceeded in some women already susceptible to cardiac insult. Spesific therapy for PPCM can not be determined. Bromocriptine that blocks the release of a hormone called prolactine from the pituitary gland in some preliminary studies improved left ventricular ejection fraction significantly. Further research with larger sample size remains to be done for this therapy. Management principles for PPCM are recommended in accordance with the pathophysiology. Depending on the volume status, preload has to be optimized by either fluid administration or sodium restriction and diuretics, decrease afterload using vasodilator, and improve contractility by using inotropic, dromotropic, or inodilator are the main strategies. There is no change in management strategy for PPCM, but regional analgesia/anesthesia preferably for now. Understanding the dose and concentration administration of local anesthethic drugs are important to achieve targets recommendation.
\end{abstract}

Key words: peripartum cardiomyopathy, management therapy for PPCM, regional anesthesia 